\title{
Use of viscosupplementation for the recovery of active football players complaining of knee pain [Corrigendum]
}

Migliore A, Giannini S, Bizzi E, Massafra U, Cassol M, Michael Abilius MJ, Boni G. Open Access Journal of Sports Medicine. 2019;10:11-15.

Following publication, the authors of this article discovered an error on page 12, in Methods section, 3rd paragraph, 4th row regarding name and affiliation of hyaluronic acid applied in this study. Correct name and provenance is SINOVIAL $8 \mathrm{mg}$ / $\mathrm{mL}$ (IBSA Farmaceutici, Italy).

\section{Publish your work in this journal}

Open Access Journal of Sports Medicine is an international, peerreviewed, open access journal publishing original research, reports, reviews and commentaries on all areas of sports medicine. The manuscript management system is completely online and includes a very quick and fair peer-review system. Visit http://www.dovepress. com/testimonials.php to read real quotes from published authors. 